\title{
A Linguagem dos Direitos Subjetivos e as Liberdades Individuais: entre Permissões, Poderes e Imunidades
}

\author{
The Language of Subjective Rights and the Individual \\ Freedoms: Between Privileges, Powers and Immunities
}

\section{El Lenguaje de los Derechos Subjetivos y las Libertades Individuales: entre Permisos, Poderes e INMUNIDADES}

1 Introdução. $2 \mathrm{O}$ uso da linguagem dos direitos subjetivos. 3 Liberdadesdireitos. 3.1 Permissões e autorizações. 3.2 Poderes e autoridade. 3.3 Imunidades. 4 Uma estrutura molecular. $4.1 \mathrm{Um}$ exemplo de estrutura molecular e complexa: o caso do direito à propriedade privada. 5 Considerações finais. Referências.

\section{RESUMO}

Objetivo: $\mathrm{O}$ artigo aborda a linguagem dos direitos subjetivos, tendo como referência o significado que a palavra "direitos" adquire quando empregada no sentido de liberdades individuais. A pergunta que se pretende enfrentar ao longo do texto é a seguinte: quais os significados que a expressão "direitos" pode adquirir quando usada, linguisticamente, como uma liberdade individual tanto na linguagem ordinária do senso comum quanto

\footnotetext{
* Professor da Escola de Direito da Universidade do Vale do Rio dos Sinos - Unisinos. Professor Pesquisador do Programa de Pós-Graduação em Direito da Unisinos. Professor dos Cursos de Graduação em Direito e Relações Internacionais da Unisinos. Coordenador do Curso de Graduação em Direito da Unisinos. Integra o Núcleo Docente Estruturante (NDE) do Curso de Direito da Unisinos. Doutor em Filosofia (2013); Mestre em Filosofia (2009); Licenciado e Bacharel em Filosofia (2007); Bacharel em Direito (2007) pela Unisinos. Tem experiência nas áreas de Filosofia e Direito, centrando-se na relação entre Moral, Política e Direito. Pesquisa, principalmente, os seguintes temas: Hume, Empirismo; Kant; Hobbes, Contratualismo; Kelsen, Positivismo Jurídico; Direitos Humanos, Direitos Naturais, Direitos Morais, Fundamentação. É advogado. São Leopoldo, RS, BR. E-mail: <aolivierdasilva@yahoo.com.br>.https://orcid.org/0000-0003-2828-0596
} 
segundo a perspectiva dos especialistas (legisladores, magistrados, etc.) de um sistema jurídico?

Metodologia: Para responder à indagação proposta, pretende-se apontar, com base no método empírico-analítico, o qual descreve o funcionamento da linguagem jurídica, que os usos da palavra "direitos", enquanto liberdades individuais, dizem respeito, basicamente, a permissões, poderes e imunidades. Direitos são termos linguísticos que incrementam a relação jurídica e auxiliam os seres humanos a se colocarem, a partir de um determinado contexto, na posição de detentor e destinatário do direito.

Resultados: $\mathrm{O}$ artigo pretende destacar a estrutura molecular da linguagem jurídica segundo a qual os direitos se entrelaçam em conglomerados de direitos elementares costurados entre si. São direitos basilares que, ao se costurarem, formam direitos cada vez mais complexos e que desempenham funções distintas entre os pares de uma relação jurídica, obrigando-os mutuamente.

Contribuições: A conclusão que se pretende extrair ao final do texto é destacar que aquilo que compreendemos como direitos são, na verdade, aglomerados de direitos elementares que formam um mosaico de direitos - também denominado cluster of rights. É justamente a sobreposição desses direitos que trazem dinâmica ao ordenamento jurídico e possibilitam a formação de novos direitos.

Palavras-chave: linguagem; direitos; direitos subjetivos; liberdades individuais.

\section{ABSTRACT}

Objective: The article addresses the language of subjective rights, having as reference the meaning of the word "rights" acquire when used in the sense of individual freedom. The question that we want to ask throughout the text is as follows: what are the meanings of the expression "rights" can acquire when used, linguistically, as an individual freedom both in ordinary language of common sense and in the perspective of specialists (legislators, magistrates, etc.) of a legal system?

Methodology: To answer the proposed inquiry, it can be pointed out, based on the empirical analytical method, which describe the operating code of legal language, that the uses of the word "rights", while individual freedoms, it which concern, basically, licke privileges, powers and immunities. Rights are linguistic terms that enhance the legal relationship and help human beings to be placed, from a certain context, in the position of holder and recipient of the right.

Results: The article intends to highlight the molecular structure of the legal language according to which rights are intertwined in conglomerates of elementary rights estitched for by each other. They are basic rights, which, if funded, form increasingly 
complex rights and perform different functions between the pairs of a legal relationship, forcing them mutually.

Contributions: The conclusion that intends to extract the final text is to highlight what comprises rights are, in fact, clusters of elementary rights that form a mosaic of rights also called a cluster of rights. It is only an overlapping of these rights that brings legal permission and enables the formation of new rights.

Keywords: language; rights; subjective rights; individual freedoms.

\section{RESUMEN}

Objetivo: El artículo aborda el linguaje de los derechos subjetivos, tendiendo como referencia o significado que la palabra "derechos" Adquiere cuando se emplea en el sentido de las libertades individuales. La pregunta que se pretende abordar en la extensión del texto es la siguiente: ¿cuáles son los significados que puede adquirir la expresión "derechos" cuando se utiliza, lingüísticamente, como una libertad individual tanto en el lenguaje ordinario del sentido común como según la perspectiva de dos especialistas (legisladores, magistrados, etc.) de un sistema legal?

Metodología: Para responder a la pregunta propuesta, pretendemos invocar, basado en el método empírico-analítico, que describe cómo funciona el lenguaje legal, que los usos de la palabra "derechos", como libertades individuales, se refieren básicamente a permisos, poderes e inmunidades. Derechos son términos lingüísticos que aumentan la relación jurídica y ayudan al ser humano a posicionarse, desde un contexto determinado, en la posición de titular y receptor del derecho.

Resultados: El artículo pretende destacar la estructura molecular del lenguaje jurídico al que se entrelazan las directivas en conglomerados de directivas elementales cosidas entre sí. Hay principios básicos que, a medida que se van cosiendo, se van convirtiendo en principios cada vez más complejos, que cumplen distintas funciones entre pares de una relación jurídica, vinculantes entre sí.

Contribuciones: La conclusión que se pretende sacar al final del texto es resaltar que lo que entendemos como derechos son, de hecho, grupos de derechos elementales que forman un mosaico de derechos, también llamado cluster of rights. Es precisamente la superposición de estos derechos lo que dinamiza el sistema legal y permite la formación de nuevos derechos.

Palabras clave: lenguaje; derechos; derechos subjetivos; libertades individuales.

\section{INTRODUÇÃO}

No cenário jurídico, e fora dele, costumamos empregar a palavra "direitos" quando estamos autorizados a realizar determinada ação ou quando podemos possuir 
A linguagem dos direitos subjetivos e as liberdades individuais: entre permissões, poderes e imunidades

algo conosco, em nossa posse, como o direito à propriedade ${ }^{1}$ de um bem. O termo "direitos" é usado, na maior parte das vezes, como sinônimo para se referir à liberdade, isto é, como um direito subjetivo. Aquele que possui um direito é livre - no sentido de que tem permissão ou está autorizado - para dispor desse direito da maneira como quer a sua vontade. Mas, será que a palavra "direito", quando empregada no sentido de uma liberdade, é sempre usada na linguagem jurídica com o mesmo e único significado? $\mathrm{Na}$ verdade, quando empregamos a palavra "direitos" no contexto de uma relação obrigacional, costumamos nos referir a essa palavra a partir de diversos significados. Mas quais são esses sentidos possíveis para a palavra "direitos" quando entendidos enquanto liberdades individuais?

Podemos dizer que a linguagem dos direitos pode ser compreendida a partir do uso que juristas, legisladores e pessoas do senso comum ${ }^{2}$ fazem de palavras como "direitos”, "leis”, “contratos”, “obrigações”, dentre tantos outros termos jurídicos. Ao seguir o método empírico-analítico, como propõe a tradição realista norte-americana e anglo-saxônica, é possível a observação de alguns tipos básicos de direitos, como as liberdades e as exigências ${ }^{3}$. Esses tipos básicos constituem as peças que, quando reunidas

\footnotetext{
${ }^{1}$ A Constituição da República Federativa do Brasil de 1988 resguarda o direito à propriedade privada em seu artigo $5^{\circ}$, XXII, desde que atendida a sua função social (art. $5^{\circ}, \mathrm{XXV}$ ). O artigo $5^{\circ}$ da $\mathrm{CF} / 88$ dispõe que a pequena propriedade rural não será objeto de penhora para pagamento de débitos decorrentes de sua atividade produtiva (XXVI); dispõe, ainda, sobre os impostos que recaem sobre a propriedade (art. 153, CF/88), bem como sobre a competência da União para desapropriar para fins de reforma agrária (art. 184, CF/88), deixando de fora a pequena e média propriedades produtivas (art. 185, CF/88). Observem que o texto constitucional dispõe sobre vários direitos subjetivos que recaem sobre a propriedade privada, de modo que podemos identificar o emprego de vários sentidos para o uso da propriedade.

${ }^{2}$ No parágrafo anterior, foi mencionado que, no cenário jurídico, assim como fora dele, costumamos empregar a palavra "direitos". Nesse sentido, convém alertar que o termo "direitos" é também usado em contextos não estritamente jurídicos, como nos contextos morais e políticos, do mesmo modo, por exemplo, no contexto de um jogo, quando se joga um jogo constituído por regras. No futebol, o goleiro tem o direito de tocar com a mão na bola somente dentro da grande área; os demais jogadores nunca podem tocar a bola com as mãos, com exceção da cobrança de lateral, quando é permitido o uso das mãos. Todo sistema de regras é, assim, composto por permissões e proibições. No presente artigo, vamos tentar focar a linguagem dos direitos para os denominados "direitos legais" ou "direitos jurídicos", visto que são diretos reconhecidos e positivados em um sistema jurídico. Mas, eventualmente, vamos fugir do contexto estritamente jurídico para mencionar o uso dos direitos na linguagem comum e ordinária.

${ }^{3}$ Desse modo, os direitos são, basicamente, liberdades e exigências. No caso das liberdades, podemos, ainda, distingui-las entre permissões, poderes e imunidades. Henry Campbell Black, em seu Law Dictionary, define a palavra "direitos" e aborda a distinção entre poderes, privilégios, faculdades e exigências. Conferir Black (1990, p. 173). Wesley Hohfeld analisa uma série de relações jurídicas que se pode extrair desses significados os quais costumamos atribuir à palavra "direitos". Sobre a definição dos direitos e a distinção entre liberdades e exigências, conferir também: (CLAYTON, 2009; EDMUNDSON, 2004, p. 90; FEINBERG, 1970, p. 253; FEINBERG, 1973, p. 56; JONES, 1994, p. 12-13; MACKIE, 1990, p. 173; PENNER, 1997, p. 300; PLATTS, 2010, p. 319; RAINBOLT, 1993, p. 93; WENAR, 2005, p. 285; WENAR, 2008, p. 251; WENAR, 2015, online; WHITE, 1984, p. 67 e p. 115).
} 
em uma só composição, formam a grande engrenagem dos direitos dentro de um sistema jurídico. No caso dos direitos-liberdades, podemos observar que aquilo que chamamos com a palavra "direitos" diz respeito, basicamente, a "permissões", "poderes" e "imunidades". Nesse sentido, o presente artigo pretende analisar detalhadamente os direitos subjetivos, entendidos como permissões, poderes e imunidades, para, ao final, mostrar que esses significados podem ser unidos e aglutinados entre si a partir de múltiplas combinações, ocasionando, com isso, conglomerados de direitos (cluster of rights). A reunião desses direitos em composições individuais é o que constitui aquilo que, tanto na linguagem ordinária quanto na linguagem técnica empregada por juristas e legisladores, costumamos nos referir com o termo "direitos".

\section{O USO DA LINGUAGEM DOS DIREITOS SUBJETIVOS}

O que significa dizer que alguém possui um direito (right) enquanto liberdade individual? Para compreender o significado do termo "direito", é preciso abordar não apenas as propriedades formais da linguagem jurídica, mas, principalmente, os usos que cidadãos, juntamente a juristas e legisladores, fazem da linguagem jurídica e os sentidos que expressões, como "direitos" e "liberdades individuais", vão adquirindo na medida em que se desenvolve a produção normativa de um sistema jurídico. Nesse sentido, o primeiro passo da investigação científica sobre a natureza dos direitos-liberdades é a observação empírica do modo como as pessoas usam a palavra "direitos" em seus negócios jurídicos. Cidadãos podem firmar pactos entre si e, amparados pela legalidade, estabelecer direitos e deveres mutuamente; o mesmo ocorre na relação do Estado com seus cidadãos, visto que o cidadão possui direitos oponíveis às instâncias burocráticas estatais e gera expectativas quanto às ações do Estado.

A observação empírica do fenômeno jurídico é um dos traços marcantes do realismo jurídico e visa observar, distinguir e analisar, conceitualmente, os elementos que compõem um sistema jurídico. Os elementos que compõem o sistema jurídico são, no fundo, as palavras que constituem a produção normativa do ordenamento jurídico, palavras como "norma”, "direitos", "deveres”, dentre tantos outros termos usados nos negócios jurídicos. Herbert Hart, ao seguir a metodologia proposta por dois pensadores homônimos - a saber, o jurista John Austin (1790-1859) ${ }^{4}$ e o filósofo da linguagem John Langshaw Austin (1911-1960) ${ }^{5}$-, que, por sua vez, seguem o utilitarismo de regras

\footnotetext{
${ }^{4}$ John Austin propõe uma análise linguística dos termos empregados pelos juristas. Conferir: Austin (2005).

${ }^{5}$ John Langshaw Austin analisa como os termos linguísticos provocam mudanças nas práticas ordinárias realizadas pelas pessoas, dando subsídios para a compreensão de como o uso de termos linguísticos alteram a prática jurídica. Conferir: Austin (1975).
} 
contido na obra de Jeremy Bentham6, afirma que essas palavras não podem ser analisadas isoladamente, pois só fazem sentido quando empregadas em proposições compostas por verbo, sujeito e predicado. Temos que observar o que diz a legislação e como funciona, na lide forense, a elaboração, por exemplo, de um contrato ou o proferimento de uma sentença judicial. No caso da linguagem dos direitos, devemos analisar o usa da palavra "direito" no contexto de uma obrigação jurídica entre duas partes, como o credor e o devedor, ou mesmo o cidadão e o Estado.

O significado das palavras reside no jogo de relações que se estabelece entre aquele que possui o direito e aquele que deve cumprir e garantir esse direito. Os direitos normatizam o comportamento humano e pautam, inclusive, como novas normas devem ser elaboradas. Os direitos limitam a esfera de decisão dos juízes e a dos legisladores quando legiferam e criam novas normas. $\mathrm{O}$ que resta para uma investigação filosófica dos direitos é, justamente, descrever como eles se apresentam na linguagem jurídica, como são usados por juízes e legisladores, assim como fez Hart em sua análise ao seguir o método de elucidação das palavras proposto por Bentham ao abordar o uso de termos como "direito" na prática jurídica.

Hart coloca-se ao lado de Bentham para afirmar que, quando enunciamos os direitos, estamos a nos referir a um titular de um direito, que o possui em relação a um destinatário. Diz Hart:

Ele [Bentham] disse que nunca devemos tomar essas palavras sozinhas, mas sim considerar frases inteiras nas quais elas desempenham seu papel característico. (...) Não devemos tomar o termo 'direito', mas a frase 'Você tem um direito'. (...) Essa advertência foi em grande medida ignorada, e os juristas continuaram insistindo em palavras isoladas (HART, 2010, p. 29).

Em linhas gerais, pode-se dizer que os "direitos" estão presentes em dois tipos de proposições: quando se afirma " $\chi$ tem ou possui um direito B"; ou quando se afirma " $\chi$ tem ou possui um direito B em relação a Y". No primeiro tipo de proposição, o titular do direito dispõe desse direito conforme as suas escolhas e sem dar satisfação a terceiros, por exemplo, quando o proprietário de um bem imóvel (uma casa ou um apartamento) usa os cômodos de sua residência do modo como ele próprio considerar o mais adequado. É claro que há limites legais para o uso da propriedade, mas sempre há um domínio de discricionariedade que é conferido ao comportamento e à conduta do portador do direito. $\mathrm{O}$ proprietário pode decorar o ambiente conforme o seu gosto estético, pode dispor do lugar dos móveis e usá-los como e na hora em que bem

\footnotetext{
${ }^{6}$ Conferir também Jeremy Bentham: (BENTHAM, 2012).

${ }^{7}$ [He [Bentham] said we must never take these words alone, but consider whole sentences in which they play their characteristic role. (...) We must take not the word 'right' but the sentence 'You have a right', (...) His warning has largely been disregarded and jurists have continued to hammer away at single words.] (HART, 1983, p. 26, grifo do autor).
} 
entender. Trata-se, nesse sentido, de um direito subjetivo do proprietário, um direito que atribui ao proprietário a capacidade de escolha e a possibilidade de exercer o seu direito conforme o seu interesse.

No caso do segundo tipo de proposição, verifica-se a relação entre o possuidor de um direito e o seu destinatário, isto é, uma relação obrigacional entre aquele que possui o direito e aquele que deve realizar algo para que o direito do portador seja resguardado. Trata-se, também, de direito subjetivo, pois ao titular do direito é conferida a possibilidade de exercê-lo de várias maneiras, por exemplo, quando as partes de um contrato - como os contratos que se prestam à alienação da propriedade privada, como a compra e venda, a doação, dentre outros - estabelecem, de forma mútua e em comum acordo, direitos e deveres para ambos os lados; ou mesmo quando um magistrado reconhece o direito do proprietário recuperar a sua propriedade que havia sido ocupada ilegalmente por terceiros. O proprietário não só tem o direito de gozar e dispor da sua propriedade, como tem também o poder de criar novas relações jurídicas a partir dela, ou tem também o direito de permanecer imune a que terceiros, em determinadas situações, possam vir a causar dano à sua propriedade. Em todos esses casos que envolvem liberdades individuais, deve haver o reconhecimento jurídico do direito subjetivo, e esse reconhecimento pode ser enunciado, linguisticamente, em proposições que possuem a seguinte estrutura lógica: " $X$ tem um direito a $B$ em relação a $Y$ ".

A linguagem dos direitos pode ser investigada a partir de suas propriedades formais. Pode-se analisar o significado da palavra "direitos", conectando-o a frases e proposições linguísticas; podem-se estabelecer relações entre as palavras usadas nas proposições que são enunciadas por juristas e legisladores; mas, mais importante do que abordar o significado restrito da palavra "direito", é descrever e analisar os usos que fazemos da nossa linguagem quando usamos termos, como "direitos" e "liberdades".

Ter um direito significa possuir um título ${ }^{8}$ que autoriza alguém a fazer ou possuir algo, ou, ainda, um título para que outros façam ou deixem de fazer, conforme afirma McCloskey ao dizer que direitos são "(...) títulos para fazer, ter, desfrutar ou ter feito." (MCCLOSKEY, 1965, p. 118, tradução nossa) ${ }^{9}$. McCloskey diz, ainda, ao propor um

\footnotetext{
${ }^{8}$ Os direitos são definidos, formalmente, a partir de um título (entitlement) que o constitui enquanto um direito legal. Aquele que possui um direito está, digamos assim, intitulado a algo, isto é, está legalmente autorizado a praticar uma determinada ação, ou a possuir um bem ou ainda está autorizado a não fazer ou praticar determinada ação. O título confere a autorização que o detentor precisa para exercer o seu direito, como o título de propriedade do imóvel, que autoriza o proprietário a dispor do seu próprio bem. Segundo afirma Olivier: "A tradição dogmática dirá que todo direito pressupõe um título (entitlement), ou uma autorização ou permissão para fazer ou possuir algo, ou para que os outros façam ou deixem de fazer." Trata-se de um certificado que confere bens, vantagens e benefícios ao portador (que, no caso dos direitos humanos, é o ser humano, mas que pode ser também uma pessoa jurídica), abrindo-lhe um leque de possibilidades para escolher em conformidade com aquilo que julga mais racional para o seu agir." (OLIVIER, 2014, p. 1105-1106).

${ }^{9}$ (...) are entitlements to do, have, enjoy or have done (MCCLOSKEY, 1965, p. 118).
} 
conceito positivo para definir os direitos, que estes "são melhor explicados positivamente como títulos para fazer, ter, desfrutar, ou ter que fazer, e não negativamente como algo contra os outros, ou como algo que alguém deve ter." (MCCLOSKEY, 1976, p. 99, tradução nossa) ${ }^{10}$. Wenar também afirma que a definição dos direitos está vinculada à faculdade de fazer, ter ou realizar determinadas ações: "Direitos são títulos para (não) realizar certas ações, ou para (não) estar em certos estados; ou títulos para os outros (não) realizarem certas ações ou (não) estarem em certos estados." (WENAR, 2015, online, tradução nossa). ${ }^{11}$

Ao ter um direito, o seu detentor adquire uma permissão - ou até mais de uma para fazer, ter ou dispor de um bem, por exemplo, o vendedor e o comprador de um imóvel. O vendedor possui o direito de receber o valor do bem imóvel, assim como o comprador possui o direito de usufruir da sua propriedade conforme o seu interesse. Ambos possuem direitos e deveres. Há também o caso de obrigações entre cidadãos e Estado, quando, no outro polo das relações jurídica, consta o Estado, que ora deve se omitir e deixar de fazer determinados atos contra os seus cidadãos, ora deve agir e interferir na vida das pessoas para garantir educação, saúde, dentre outros direitos sociais. No presente artigo, pretende-se abordar apenas o caso dos direitos subjetivos e das liberdades individuais, deixando para outro momento a análise das exigênciasdireitos ${ }^{12}$.

\section{LIBERDADES-DIREITOS}

Os direitos subjetivos são, geralmente, relacionados a faculdades, poderes, permissões, discricionariedades ou a qualquer outro termo que queira se referir à possibilidade de escolha e decisão que se abre no horizonte do seu detentor. Direitos são liberdades que sempre remetem a uma ideia de autorização ou permissão. Tais liberdades estão contextualizadas em um jogo de relações lógicas entre os direitos individuais e as partes envolvidas na relação jurídica. Quando alguém diz que possui um direito é porque há um destinatário que tem o dever de efetivar esse direito, ou seja, os direitos desempenham funções distintas ao seu portador e exigem demandas também distintas do seu destinatário.

No caminho da reflexão analítica da linguagem dos direitos, o jurista estadunidense Welsey Newcomb Hohfeld classificou os direitos subjetivos como direitos

\footnotetext{
${ }^{10}$ Rights, I suggest, are best to be explained positively as entitlements to do, have, enjoy, or have done, and not negatively as something against others, or as something one ought to have. They are things that one has, that one possesses independently of other people and independently of what else ought to be (MCCLOSKEY, 1976, p. 99).

${ }^{11}$ Rights are entitlements (not) to perform certain actions, or (not) to be in certain states; or entitlements that others (not) perform certain actions or (not) be in certain states (WENAR, 2015, online).

${ }^{12}$ Conferir artigo sobre exigências por direitos: Olivier (2014, p. 1123).
} 
em forma de permissões, poderes e imunidades. A proposta de Hohfeld é analisar o conceito de direito-liberdade em sua estrutura elementar para, a posteriori, reunir os elementos básicos em um conjunto de direitos que, muitas vezes, são constituídos não só por uma permissão ou um só poder ou imunidade, mas também por múltiplas permissões, poderes e/ou imunidades. Na verdade, o referencial teórico anglo-saxônico distingue os direitos-liberdades em privilégios (privileges), poderes (powers) e imunidades (immunities). No presente artigo, optou-se por adotar a expressão "permissão” ao invés de privilégio como uma das definições possíveis para a palavra "direito". A razão para tal escolha é porque o termo "privilégio" 13 pode confundir o leitor ao sugerir que o direito é algo arbitrário, concedido apenas para alguns privilegiados. Autores como Clayton irão usar a classificação de Hohfeld, mas irão substituir o termo privilégio pela palavra "liberdade":

Em sua análise clássica, Hohfeld identificou quatro diferentes tipos de relações jurídicas que podem ser descritas como títulos: uma exigência por direito, em que uma pessoa assere que tem uma exigência sobre outra; um direito de liberdade, que autoriza uma pessoa a fazer o que quiser por, por exemplo, a fumar; um poder, segundo o qual uma pessoa está habilitada ou empodeirada a, por exemplo, votar; e uma imunidade, que protege uma pessoa do poder de outra, como no caso de uma constituição foritificada que impede o legislador de substituir direitos constitucionais (CLAYTON, 2009, p. 21, grifos do autor, tradução nossa). ${ }^{14}$

Independentemente da nomenclatura adotada, o raciocínio é o mesmo para se compreender a complexidade da linguagem dos direitos enquanto liberdades (liberty) ${ }^{15}$, e

13 Os direitos são confundidos com privilégios porque, historicamente, estão relacionados a uma qualificação que alguém goza, por exemplo, os títulos conferidos pelas Monarquias Absolutistas no início da Idade Moderna. Esses títulos eram dados pela Realeza e constituíam desde a propriedade privada até as honrarias que seriam ostentadas por aristocratas proprietários de grandes latifúndios de terras. Esses títulos eram usados para distinguir e diferenciar determinadas pessoas da sociedade por seus diversos atributos, como o fato de serem homens, brancos e proprietários. Ocorre que, com a queda do Absolutismo e com o advento do Estado Liberal de Direito, os direitos ganharam um sentido muito mais republicano e democrático, embora, ainda hoje, seja possível encontrar privilégios distribuídos para determinadas classes sociais.

${ }^{14}$ In his classic analysis, Hohfeld identified four different types of legal relations which might be described as entitlements: a claim right, where one person asserts he has a claim on another; a liberty right, which authorizes a person to do as he pleases by, for example, smoking; a power, by which a person is enable or empowered, for example, to vote; and an immunity, which protects a person from the power of another, as in the case of an entrenched constitution which precludes the legislature from overriding constitutional rights (CLAYTON, 2009, p. 21, grifos do autor).

${ }^{15}$ Não é incomum, ao dizermos que "A possui um direito $\chi$ em relação a B", imaginarmos que o termo "direito" diga respeito a uma liberdade metafísica (nos moldes da liberdade kantiana e no sentido de freedom), porém, nessa armadilha metafísica, não queremos tropeçar, de modo que, neste texto, estamos a nos referir estritamente à liberdade jurídica, isto é, a uma criação jurídica que é inventada para legitimar e permitir o exercício do querer do seu portador sem a imposição de obstáculos ao seu agir seja por parte do destinatário, seja por parte de terceiros à relação. Outros equívocos também 
o próximo passo da presente investigação é a análise da definição dos direitos como sinônimos de "liberdade", isto é, como "direitos de liberdade", ou direitos subjetivos, como é o caso das permissões, dos poderes e das imunidades que a legalidade outorga ao titular do direito. Antes de adentrarmos às partes que compõem aquilo que costumam nos referir com o uso da palavra "direito", faz-se necessário arrolar um último esclarecimento para darmos continuidade à presente investigação. Esse esclarecimento diz respeito a uma distinção entre direitos que recaem diretamente sobre a conduta ou o comportamento humano (como as permissões) e direitos que se dirigem a outros direitos, isto é, direitos (de segunda ordem) que recaem sobre os direitos (de primeira ordem) de conduta. Com base nessa distinção, que vamos desenvolver nos próximos capítulos, podemos começar a enxergar as primeiras diferenças entre permissões, poderes e imunidades.

\subsection{PERMISSÕES E AUTORIZAÇÕES}

O primeiro tipo de liberdade é a “permissão”, que é também entendido sob o contexto das obrigações ${ }^{16}$, quando alguém diz que possui um direito a $R$ em relação a $Y$. A permissão é um tipo de direito que pode ser compreendido a partir da proposição "X tem ou possui um direito", pois, independentemente de sua relação com o destinatário, o exercício dessa liberdade depende diretamente da atividade do seu detentor. Trata-se de um direito de primeira ordem ${ }^{17}$, isto é, um direito que recai diretamente sobre o comportamento e a conduta do titular da permissão.

A permissão é uma espécie de prerrogativa ou atribuição que alguém possui e pode exercê-la conforme o seu interesse. Ter um direito-permissão é estar autorizado a

podem aparecer com relação ao emprego de termos, como "liberdade" (liberty) e "poder" (power), no sentido de uma liberdade política. Com efeito, é necessário destacar que, neste artigo, queremos destacar a estrutura das relações jurídicas, por isso, aqui, não estamos a refletir sobre as obrigações morais e políticas.

${ }^{16} \mathrm{O}$ contexto das obrigações diz respeito à atributividade entre um sujeito de direito e o seu destinatário. Os direitos surgem em obrigações constituídas pela bilateralidade que vincula aquele que possui um direito àquele que deve cumprir a sua contrapartida para que o direito seja efetivado.

${ }^{17}$ Mais à frente do texto, voltaremos ao esclarecimento inicialmente proposto entre direitos de primeira ordem e direitos de segundo ordem. Convém destacar, neste momento, que as permissões constituem direitos subjetivos de primeira ordem, pois a permissão gravita em torno do comportamento e da conduta do titular do direito. Com isso, estabelecemos, segundo Sumner, um sistema estático de regras composto apenas por exigências e privilégios: “(...) o sistema de regras que temos até agora imaginado é totalmente estático: ele contém regras que determinam as relações de primeira ordem sobre aqueles a quem se aplica o sistema, seja por meio da imposição de deveres, seja ao conferir exigencias e liberdades, mas não contém qualquer mecanismo para a criação, alteração, extinção ou manipulação dessas relações." (SUMNER, 1987, p. 27, tradução nossa) [(...) the rule system which we have thus far imagined is entirely static: it contains rules which determine the first-order relations of those to whom the system applies, either by imposing duties or by conferring claims and liberties, but it contains no mechanism for creating, altering, extinguishing, or otherwise manipulating these relations. (SUMNER, 1987, p. 27)]. 
algo, como fazer o que bem entender com a sua propriedade privada. Imaginemos um proprietário de uma casa que se encontra averbada em seu nome no Registro de Imóveis do seu município. O título da propriedade lhe confere uma licença, ou mesmo um privilégio, que o autoriza a usar, dispor e gozar da sua casa como bem entender. A licença dá permissão, de modo que o proprietário possa realizar benfeitorias no imóvel, derrubar as paredes e trocar as esquadrias, reformar a casa inteira, contratar um pintor para realizar a pintura dessas paredes, enfim, deixar a janela sempre aberta e emprestar um de seus cômodos para convidados. O título da propriedade lhe atribui liberdade para se relacionar do modo como bem entender não apenas com a propriedade privada, mas também em relação a terceiros que, por alguma razão, possam vir a se inserir em uma nova obrigação jurídica.

A permissão é quase o mesmo que possuir um privilégio ou uma regalia sobre uma coisa, pois o proprietário, ao contrário de terceiros, e somente o proprietário, pode escolher como irá dispor do seu próprio bem. Enquanto o titular do direito possui, então, a autorização para adentrar dentro da casa e usufrui-la do modo que mais lhe aprouver, outras pessoas - como um prestador de serviços ou mesmo o vizinho do terreno ao lado - não poderão reivindicar para si o mesmo direito e, dependendo do caso, possuirão, até mesmo, um dever perante aquele direito embrionário que é o direito à propriedade privada.

O titular do direito, ao possuir uma licença, está isento e autorizado a uma prerrogativa que os outros não possuem, fato que o torna desigual e em vantagem diante dos demais para realizar uma determinada ação. A permissão desobriga o seu detentor daquilo que, para os outros, é um dever, conforme afirma Hohfeld ao dar o exemplo do privilégio de alguém ingressar em uma propriedade privada:

(...) um privilégio é o oposto de um dever, e o correlativo de um 'não-direito.' (...) enquanto $\mathrm{X}$ tem um direito ou exigência que $\mathrm{Y}$, o outro homem, deve ficar fora do seu pedaço de terra, ele próprio tem o privilégio de entrar na terra, ou, em palavras equivalentes, $\mathrm{X}$ não tem o dever de ficar fora. $\mathrm{O}$ privilégio de entrar é a negação de um dever de ficar fora. (...) Assim, o correlativo do direito de $\mathrm{X}$ que $\mathrm{Y}$ não deve entrar na terra é o dever de $\mathrm{Y}$ de não entrar, mas o correlativo do privilégio de $\mathrm{X}$ de entrar ele mesmo é manifestamente o "não-direito" de Y que X não deve entrar (HOHFELD, 2001, p. 14, grifos do autor, tradução nossa). ${ }^{18}$

${ }^{18}$ (...) a privilege is the opposite of a duty, and the correlative of a 'no-right.' (...) whereas $X$ has a right or claim that $Y$, the other man, should stay off the land, he himself has the privilege of entering on the land; or, in equivalent words, $X$ does not have a duty to stay off. The privilege of entering is the negation of a duty to stay off. (...) Thus, the correlative of X's right that $Y$ shall not enter on the land is $Y^{\prime}$ 's duty not to enter; but the correlative of $X$ 's privilege of entering himself is manifestly Y's "no-right" that $X$ shall not enter. (HOHFELD, 2001, p. 14, grifos do autor)]. Diz, ainda, Hohfeld: "O mais próximo sinônimo de 'privilégio' legal parece ser 'liberdade' legal." (HOHFELD, 2001, p. 17, grifos do autor, tradução nossa) [The closest synonym of legal 'privilege' seems to be legal 'liberty'. (HOHFELD, 2001, p. 20). 
A permissão constitui uma liberdade que diz respeito apenas à ação do seu próprio titular, pois, enquanto as outras pessoas estão sob o crivo de um dever, o portador da permissão está liberado dele, no sentido de que esse tipo de direitoliberdade se constitui em oposição ao dever e em correlação com um não direito (noright, no sentido de no-claim-right). Em razão disso, é independente das exigências-direitos e oposto ao dever. "O tipo de direito aqui é o que Hohfeld chamou de "privilégio", que é também chamado por uma "liberdade" ou uma "licença". (...) Um direito que é um único privilégio confere uma isenção perante um dever geral.” (WENAR, 2005, p. 226, grifo do autor, tradução nossa) ${ }^{19}$. Nesse sentido, o detentor precisa, necessariamente, agir ou fazer alguma coisa para que o seu direito seja posto em prática. $\mathrm{O}$ detentor, por exemplo, precisa locomover o seu corpo para exercitar o seu direito de ir e vir, dessa forma, possuirá um privilégio ou uma permissão para decidir se quer caminhar para o lado direito ou para o esquerdo.

Em alguns casos, a função do privilégio é garantir não só a isenção e a dispensa quanto ao dever que para os outros é inevitável, como é também a de proporcionar "discrição" ou "discricionariedade" ao detentor do direito, que possui a permissão para decidir, por exemplo, se quer ou não reformar a sua casa. Wenar arrola para a permissão como um direito-licença, por exemplo, a propriedade de um automóvel e o seu uso enquanto motorista. O proprietário do automóvel pode escolher quem irá dirigir o seu carro, se ele mesmo ou se alguém para o qual ele dará autorização para assumir a direção do veículo. Wenar aponta para o privilégio que é concedido pela licença (ou pela carteira de habilitação do motorista) para dirigir um automóvel (WENAR, 2005, p. 226227).

Se repararmos com atenção, veremos que aquilo que chamamos de permissão quando nos referimos a um direito é, em alguns casos, um par de permissões, pois garante ao seu titular duas permissões. O direito à locomoção mostra, por exemplo, que a função da licença é proporcionar uma "isenção" ao seu possuidor, visto que está isento e dispensado de um dever, ao mesmo tempo em que exerce o seu "segundo" privilégio, que é a liberdade para escolher o caminho que quer trilhar com suas próprias pernas. Podemos dizer, ainda, que o motorista de um automóvel pode possuir o mesmo par de privilégios, pois, além de estar autorizado a pegar o volante, pode escolher os seus caminhos no trânsito e decidir se quer ir para a direita ou para a esquerda na estrada. Diz Wenar: "A função de um direito que é um par de privilégios é dotar seu portador com discrição, ou escolha, sobre alguma ação (...) Esses pares todos de privilégios-direitos

\footnotetext{
${ }^{19}$ The type of right here is what Hohfeld called a "privilege", which is also called a "liberty" or a "license". (...) A right that is a single privilege confers an exemption from a general duty (WENAR, 2005, p. 226, grifo do autor).
} 
intitulam o detentor do direito a escolher como agir dentro de algum domínio (...)." (WENAR, 2005, p. 227, grifo do autor, tradução nossa). ${ }^{20}$

Em outros casos, a licença parece estar anexada a uma exigência-direito, quando uma pessoa concede à outra o direito de comer consigo a sua própria refeição na hora do almoço. Reparem que, nesse exemplo, recorre-se à linguagem ordinária do senso comum e ao uso que se faz, no dia a dia, da palavra "direitos". Segundo esse exemplo de Hohfeld, uma pessoa pode dar a outra o privilégio de comer ou pegar a salada que se encontra em seu próprio prato ao mesmo tempo em que ambos exigem um do outro a não interferência quando estiverem comendo a referida salada. Por causa disso, Thomson $^{21}$ identifica não exatamente um par de permissões, como anteriormente identificou Wenar, mas, sim, uma licença e uma exigência de não interferência, no seguinte exemplo: "Se assim for, então não há tal coisa como o direito que você dá a Bloggs ao dar-lhe permissão para comer sua salada, pois você deu-lhe dois: o privilégio de comê-la (se o privilégio é um direito) e uma exigência de não-interferência com o seu ato de comê-la." (THOMSON, 1990, p. 51, grifo do autor, tradução nossa). ${ }^{22}$

Outro exemplo de direito constituído a partir da junção entre exigência e permissão é dado por Wenar ao abordar o direito do suspeito permanecer calado em um interrogatório policial. Esse direito implica a "exigência" para que o policial não force o suspeito a falar e confessar o crime, bem como a garantia do suspeito para permanecer calado (WENAR, 2005, p. 229). A permissão é, então, um direito não correlato a deveres e está separado das exigências por direitos, constituído simplesmente enquanto liberdade, no sentido de que o seu detentor pode possuir um direito $Q$, sendo que $\mathrm{Q}$, para as demais pessoas, se apresenta na forma de dever.

\footnotetext{
${ }^{20}$ The function of a right that is a paired privilege is to endow its bearer with discretion, or choice, concerning some action. (...) These paired privilege-rights all entitle the rightholder to choose how to act within some domain (...) (WENAR, 2005, p. 227, grifo do autor).

${ }^{21}$ No caso do direito como "licença", dada uma relação jurídica entre X, o titular do direito, e Y, o seu destinatário, Judith Thomson afirma: "X tem no que se refere a Y um privilégio de deixá-lo ser o caso que p" (THOMSON, 1990, p. 44, tradução nossa) [ $X$ has as regards $Y$ a privilege of letting it be the case that p (THOMSON, 1990, p. 44)]. Segundo a formalização lógica dos direitos, a relação jurídica com base na noção de licença pode ser expressa da seguinte maneira: $P_{x, y} p \leftrightarrow \neg D_{x, y} \neg p$. Afirma Thomson: "X está sob um dever em relação a $Y$, nomeadamente o dever que $X$ exonere se e somente se não-p. (...) $\left(\mathrm{H}_{2}\right) \mathrm{P}_{\mathrm{x}, \mathrm{y}}$ é equivalente a Não-( $\mathrm{D}_{\mathrm{x}, \mathrm{y}}$ Não-p).” (THOMSON, 1990, p. 45, tradução nossa) $[X$ is under a duty toward $Y$, namely the duty that $X$ discharge if and only if not-p. (...) $\left(\mathrm{H}_{2}\right) P_{x, y}$ is equivalent to Not- $\left(D_{x, y}\right.$ Notp). (THOMSON, 1990, p. 45)]. Afirma, novamente, Wenar: "“A tem um Y direito a phi” implica tanto "A não tem o dever Y para não phi” e "A não tem o dever Y para phi"." (WENAR, 2005, p. 226, tradução nossa) ["A has a Y right to phi" implies both "A has no Y duty not to phi" and "A has no Y duty to phi”. (WENAR, 2005, p. 226)].

${ }^{22}$ If so, then there is no such thing as the right you give Bloggs in giving him permission to eat your salad, for your give him two: the privilege of eating it (if his privilege is a right) and a claim to noninterference with his eating it (THOMSON, 1990, p. 51, grifo do autor).
} 


\subsection{PODERES E AUTORIDADE}

O "direito" é também entendido como um "poder" e, assim como a licença, é compreendido a partir do detentor e, portanto, a partir da proposição "X possui um direito B". "O poder, como o privilégio, é indicado por proposições da forma "A tem um direito a phi”.", afirma Wenar (WENAR, 2005, p. 231, grifo do autor, tradução nossa $)^{23}$. Assim como ocorre em todos os direitos-liberdades, o poder é também um tipo de liberdade conferida ao seu titular, que o autoriza a agir conforme a sua escolha, independentemente do seu destinatário, isto é, cabe ao titular exercer o seu poder, enquanto ao destinatário cabe não fazer nada, no sentido de garantir o exercício da liberdade facultada ao portador do direito.

Mais do que isso, no caso do poder, a compreensão dos "direitos" reside no fato de que o seu titular tem o poder de criar novas relações jurídicas. Trata-se, ao contrário das permissões, de um direito de segunda ordem, isto é, um direito que não recai propriamente sobre um comportamento, mas, sim, sobre outros direitos. Nesse caso, o titular do direito pode dar permissões a terceiros e, com isso, ocasionar novos direitos e novas relações jurídicas.

O proprietário pode, por exemplo, autorizar o empreiteiro a reformar a sua casa; pode contratar pedreiro, encanador, eletricista e autorizá-los a reformar a sua residência. Pode alugar o imóvel para terceiros ou, ainda, doar a mesma propriedade para os filhos ou para o amor da sua vida, tornando-os os reais proprietários do imóvel. Pode, enfim, criar uma série de novas relações jurídicas a partir de uma mera licença, que, no exemplo dado, é a licença que o proprietário possui de usufruir da sua propriedade, ou seja, o direito-permissão que competia apenas ao proprietário de alterar a sua propriedade pode ser transferido e delegado a terceiros, mesmo que momentaneamente, para que estes exerçam o direito que cabia, até então, só ao proprietário. Segundo Jones: "Um poder legal é geralmente definido como a capacidade legal para alterar uma relação jurídica." (JONES, 1994, p. 22, tradução nossa) ${ }^{24}$. Assim, o sujeito possui um poder quando está autorizado a manipular direitos previamente constituídos, seja a partir da renúncia ao próprio direito, seja a partir da transferência desse direito a um terceiro estranho à relação jurídica, criando, digamos assim, novos direitos, a serem exercidos por este estranho perante outra gama de relações jurídicas que se abre.

Hohfeld discorre sobre o exemplo do proprietário com relação à sua propriedade privada, mostrando que o proprietário pode abandonar a sua coisa, renunciá-la, como pode também criar novos direitos ao atribuir para outrem a permissão para acesso e usufruto da sua propriedade:

\footnotetext{
${ }^{23}$ All rights that are powers confer authority. Rights that are single powers confer nondiscretionary authority (WENAR, 2005, p. 231, grifo do autor).

${ }^{24}$ A legal power is usually defined as the legal ability to change a legal relation (JONES, 1994, p. 22).
} 
Assim, X, o proprietário da propriedade pessoal comum 'em um objeto tangível' tem o poder de extinguir seu próprio interesse legal (direitos, poderes, imunidades, etc) através dessa totalidade dos fatos operativos conhecidos como abandono; e - simultaneamente e correlativamente - para criar privilégios em outras pessoas e poderes relativos ao objeto abandonado, e. g. o poder de adquirir o título mais tarde apropriando-se dele. Similarmente, $\mathrm{X}$ tem o poder de transferir seu interesse para $\mathrm{Y}$, - isto é, para extinguir seu próprio interesse e, concomitantemente, criar em Y um novo interesse e correspondente. Portanto, $\mathrm{X}$ tem também o poder de criar obrigações contratuais de vários tipos (HOHFELD, 2001, p. 22, grifo do autor, tradução nossa). ${ }^{25}$

A função do poder é dar "autoridade" ao detentor do direito, colocá-lo em posição de autoridade ${ }^{26}$ para a formulação de novos direitos, em especial os direitos de primeira ordem, a saber, as exigências e as permissões. "Todos os direitos que são poderes conferem autoridade.” (WENAR, 2005, p. 231, grifo do autor, tradução nossa) 27. Prossegue Wenar:

Temos não só privilégios e exigências, mas direitos para alterar os nossos privilégios e exigências, e direitos que nossos privilégios e exigências não sejam alterados. (...) Os direitos que são indicados pela forma "A tem o direito a phi” têm, em suma, três funções possiveis: privilégios individuais marcam uma isenção para um dever geral; tanto os pares de privilégios quanto os pares de poderes marcam discrição dentro de um determinado domínio, e tanto os poderes individuais quanto os pares de poderes marcam autoridade para alterar a situação normativa de alguma forma (WENAR, 2005, p. 230-231, grifos do autor, tradução nossa). ${ }^{28}$

\footnotetext{
${ }^{25}$ Thus, $X$, the owner of ordinary personal property 'in a tangible object' has the power to extinguish his own legal interest (rights, powers, immunities, etc.) through that totality of operative facts known as abandonment; and simultaneously and correlatively - to create in other persons privileges and powers relating to the abandoned object,-e. g., the power to acquire title to the later by appropriating it. Similarly, $X$ has the power to transfer his interest to $Y$,that is, to extinguish his own interest and concomitantly create in $Y$ a new and corresponding interest. So also $X$ has the power to create contractual obligations of various kinds (HOHFELD, 2001, p. 22, grifo do autor).

${ }^{26}$ Logo no início do artigo, há uma nota de rodapé explicando que a linguagem dos direitos não é usada apenas em contextos jurídicos. No caso do poder, isso fica claro de se verificar quando se separa, conceitualmente, o poder da noção de "autoridade". Joseph Raz, por exemplo, usa "authority" tanto para falar de officials (autoridades públicas) e outras autoridades em termos estritos como para falar em pessoas dotadas de conhecimento superior, tidas por outros como "autoridade" em certa área. Médicos e advogados são autoridades em suas áreas respectivas. Autoridades em sentido estrito são indivíduos dotados de permissão para emitir comandos (e, plausivelmente, alguns poderes especificados). Se isso está correto, então nem toda "autorização" implica "autoridade". Alguém pode autorizar outra pessoa a usar seu celular sem que tenha qualquer autoridade sobre a pessoa. Talvez autoridades públicas tenham poderes e permissões, como o policial que pode determinar a suspensão de uma permissão e, ao mesmo tempo, exigir obediência a um comando. $O$ destinatário não está na posição legal de exigir dele que não o comande e, tendo o dever de obediência, não tem permissão para desobedecê-lo. Isso talvez valha para todo e qualquer comando legítimo. Ver: Raz (1985, p. 3-29).

${ }^{27}$ All rights that are powers confer authority (WENAR, 2005, p. 231, grifo do autor).

${ }^{28}$ We have not only privileges and claims, but rights to alter our privileges and claims, and rights that our privileges and claims not be altered. (...) The rights that are indicated by the form "A has a right to phi" have, in sum,
} 
Assim, o seu titular pode abrir mão do direito possuído ou mesmo incluir um terceiro na relação, vinculando-o ao destinatário, ao lhe conferir ou outorgar o direito que, até então, só a ele pertencia. Trata-se de um novo titular, que foge da relação obrigacional direta, mas que evidencia que o detentor primário do direito possui o "poder" de conceder direitos a outras pessoas. "Ter um poder é ter a capacidade de fazer outra pessoa ter ou deixar de ter direitos de um ou de outro tipo (...)", afirma Judith Thomson (THOMSON, 1990, p. 59, tradução nossa) ${ }^{29}$. Ao outro polo da relação jurídica, por sua vez, só restarão a sujeição e a obediência perante o poder que o detentor do direito possui e, nesse sentido, terá que se submeter à vontade dos novos titulares do direito. Wenar diz o seguinte sobre o "direito-poder": "(...) é ter a capacidade dentro de um conjunto de regras para alterar a situação normativa de si mesmo ou de outro. (...) é ter a capacidade dentro de um conjunto de regras para criar, renunciar, ou anular algum incidente(s) de ordem inferior.” (WENAR, 2005, p. 231, tradução nossa) ${ }^{30}$.

Quando tem poder, o detentor do direito está autorizado a transferir e outorgar direitos a terceiros, dotando-os de novos direitos, sejam eles entendidos como direitos, permissões, poderes ou imunidades. Wenar (WENAR, 2005, p. 230) discorre acerca do exemplo do direito do proprietário sobre a sua coisa para demonstrar como o direitopoder produz novas relações jurídicas. Imaginemos alguém que resolve doar a sua fortuna para outra pessoa e, ao fazer isso, o faz por meio da doação dotada da condição do usufruto, ou seja, o proprietário irá doar a propriedade sob a condição de que o proprietário-doador siga habitando na propriedade doada até o dia de sua morte, quando a propriedade será finalmente transferida ao nome do donatário. Por meio de uma promessa de doação com usufruto, o atual proprietário poderá criar a possibilidade de o donatário vir a exigir e reivindicar a propriedade como sua, uma exigência que coloca o doador na posição daquele que deve cumprir um dever, que consiste em doar a propriedade.

Tanto no caso do "poder" quanto no da "permissão", a simples proposição "X possui um direito B" não está de todo modo equivocada, pois o exercício do direito $\mathrm{B}$ depende muito mais do seu detentor do que propriamente do destinatário. Ao destinatário cabe uma obrigação negativa, que consiste em uma omissão ou em um não

three possible functions: single privileges mark an exemption from a general duty; both paired privileges and paired powers mark discretion within a certain domain; and both single powers and paired powers mark authority to alter the normative situation in some way (WENAR, 2005, p. 230-231, grifos do autor).

${ }^{29}(. .$.$) is to have the ability to make another person have or cease to have rights of one or another kind (...)$ (THOMSON, 1990, p. 59).

${ }^{30}(. .$.$) is to have the ability within a set of rules to alter the normative situation of oneself or another. (...) is to have$ the ability within a set of rules to create, waive, or annul some lower-order incident(s) (WENAR, 2005, p. 231). 
fazer como encargo. Ao titular do direito é que cabe uma ação e, com isso, o exercício propriamente dito do direito. Se, no caso da permissão, o detentor precisava agir e exercer o seu direito, caminhando e se locomovendo para, por exemplo, exercer o seu direito de ir e vir ou usufruindo e desfrutando a coisa que é sua para exercer o direito de propriedade; no caso do poder, o titular precisa criar outros direitos e alterar, assim, as relações jurídicas já estabelecidas.

\subsection{IMUNIDADES}

O último significado para o termo "direito" no que tange às liberdades individuais diz respeito à "imunidade", e, como todos os outros sentidos semânticos, o direito-imunidade só pode ser entendido no jogo das relações jurídicas. A imunidade consiste na isenção a um encargo que é devido a outras pessoas. Enquanto os outros estão sujeitos a um poder ou não estão autorizados a agir ou a fazer algo, o titular de uma imunidade, ao contrário daquelas pessoas, está liberado da prática desse encargo.

A imunidade surge quando alguém possui o direito de não se submeter a nenhum dos tipos de "direito" acima elencados - a saber, permissões e poderes -, mas, segundo o quadro de relações hohfeldianas (HOHFELD, 2001, p. 12), a imunidade é mais facilmente compreendida a partir do conceito de poder, pois o detentor de uma imunidade anula, digamos assim, o poder que o seu destinatário poderia possuir, incapacitando, então, o destinatário daquele poder. Nesse sentido, o detentor de um poder tem autoridade para interferir nos direitos dos outros. Porém, quando alguém está imune, o poder exercido por aquele titular é anulado diante da imunidade e, mesmo sob a posse de um poder, o seu detentor não consegue resistir à imunidade e se vê obrigado a se sujeitar ao exercício desta liberdade, conforme afirma Jones: "Possuir uma imunidade é não estar sujeito ao poder de outro.” (JONES, 1994, p. 24, tradução nossa) $)^{31}$. Na mesma linha, afirma Thomson: "X ter uma imunidade contra Y é para Y não mais do que a ausência de um poder no que diz respeito a X." (THOMSON, 1990, p. 59, tradução nossa) ${ }^{32}$. Thomson vai além e conecta a discussão sobre a linguagem dos direitos ao debate em torno da definição dos direitos humanos, que são concebidos como direitos inalienáveis. Para Thomson, “(...) se existem direitos inalienáveis, então cada um de nós tem algumas imunidades contra nós mesmos." (THOMSON, 1990, p. 59, tradução nossa) $)^{33}$.

No quadro de relações lógicas que se se estabelecem a partir das obrigações jurídicas, pode-se verificar que, a partir de uma relação de oposição, existem as

\footnotetext{
31 "To possess an immunity is to be not subject to another's power." (JONES, 1994, p. 24).

${ }^{32}$ for $X$ to have an immunity against $Y$ just is for $Y$ to lack a power as regards $X$. (THOMSON, 1990, p. 59).

${ }^{33}$ And if there are inalienable rights, then we each of us have some immunities against ourselves. (THOMSON, 1990, p. 59).
} 
A linguagem dos direitos subjetivos e as liberdades individuais: entre permissões, poderes e imunidades

imunidades de um lado e de outro, mais precisamente no domínio do destinatário do direito, existe a sujeição, pois o seu direito-poder não consegue romper com a incidência do direito-imunidade. Enquanto na oposição verifica-se uma deficiência ou desvantagem por parte daquele que não possui uma imunidade, na sua correlação lógica, encontra-se uma incapacidade, inabilidade, impotência ou inaptidão para adquirir tal imunidade. Afirma Hohfeld ${ }^{34}$ :

Um direito é a exigência afirmativa de alguém contra outro, e um privilégio é a liberdade de alguém a partir do direito ou exigência de outro. Da mesma forma, um poder é o "controle" afirmativo de alguém sobre uma dada relação legal em detrimento de outro, enquanto que a imunidade é a liberdade de alguém a partir do poder ou 'controle' legal do outro no que diz respeito a alguma relação legal (HOHFELD, 2001, p. 28, tradução nossa). ${ }^{35}$

Diz-se, portanto, que alguém está "imune" quando tem o direito de não se submeter ao poder ou à licença do titular, isto é, quando possui o direito de não se sujeitar ao direito que os outros possuem. Segundo Wenar,

\begin{abstract}
Uma pessoa tem uma imunidade sempre que outra pessoa não tiver a capacidade dentro de um conjunto de regras para mudar sua situação normativa em um aspecto particular. A imunidade, como a exigência, é sinalizada pela forma "A tem um direito que B phi” (ou, mais comumente, “... que B não phi”). Direitos que são imunidades, como muitos direitos que são exigências, entitulam os seus detentores à proteção contra danos ou paternalismo (WENAR, 2005, p. 232, grifo do autor, tradução nossa). ${ }^{36}$
\end{abstract}

Como exemplos de direitos-liberdades que se apresentam na forma de imunidades, podemos destacar o caso do parlamentar que só pode ser julgado

\footnotetext{
${ }^{34}$ Diz Hohfeld: "X, um proprietário de terras, tem, como temos visto, o poder para alienar a Y ou a qualquer outra parte comum. Por outro lado, $\mathrm{X}$ tem também várias imunidades contra $\mathrm{Y}$, e todas as outras partes comuns. Para Y estar sob uma sujeição (ou seja, não ter poder) tanto quanto deslocando o interesse legal, quer para si ou para um terceiro está em causa, e o que é verdade de Y se aplica igualmente a qualquer outra pessoa que não tenha, em virtude de fatos operativos especiais, adquirido um poder de alienar bens de X." (HOHFELD, 2001, p. 28, tradução nossa) [X, a landowner, has, as we have seen, power to alienate to $Y$ or to any other ordinary party. On the other hand, $X$ has also various immunities as against $Y$, and all other ordinary parties. For $Y$ is under a disability (i. e., has no power) so far as shifting the legal interest either to himself or to a third party is concerned; and what is true of Y applies similarly to every one else who has not by virtue of special operative facts acquired a power to alienate X's property (HOHFELD, 2001, p. 28)].

${ }^{35} \mathrm{~A}$ right is one's affirmative claim against another, and a privilege is one's freedom from the right or claim of another. Similarly, a power is one's affirmative 'control' over a given legal relation as against another; whereas an immunity is one's freedom from the legal power or 'control' of another as regards some legal relation (HOHFELD, 2001, p. 28).

${ }^{36}$ One person has an immunity whenever another person lacks the ability within a set of rules to change her normative situation in a particular respect. The immunity, like the claim, is signaled by the form "A has a right that B phi" (or, more commonly, "... that B not phi"). Rights that are immunities, like many rights that are claims, entitle their holders to protection against harm or paternalism (WENAR, 2005, p. 232, grifo do autor).
} 
criminalmente após autorização do Congresso e do Supremo Tribunal Federal ${ }^{37}$. Esse parlamentar está imune ao poder de investigação da justiça comum. No plano internacional, podemos pensar no caso dos diplomatas ou no da imunidade diplomática, em que os diplomatas possuem o denominado "salvo conduto" emitido ao longo de uma guerra para que o diplomata possa cruzar o campo de batalha imune, sem sofrer os obstáculos que os militares deste ou daquele exército iriam imputar a qualquer indivíduo que intentasse fazer o mesmo. No caso do salvo conduto, diplomatas possuem não apenas um direito-permissão, mas também a autorização para exigir o imediato cumprimento do salvo conduto que o autoriza à locomoção no campo de batalha (aqui estaríamos a pensar em uma liberdade que também adquire a forma de um direitoexigência, no sentido de claim-right), e podem ter imunidade quanto a ambos os direitos.

A diferença aqui é sutil e exige de nós um pouco de atenção, tendo em vista que, ao falarmos em imunidade, podemos resvalar nas armadilhas da linguagem e usar sinônimos como "permissão" e "poder". Podemos, aliás, dizer que, no caso da permissão e do poder, afirma-se meramente que "X possui um direito", mas, no caso da imunidade, deve-se dizer que "X possui um direito B em relação a Y". Diplomatas não possuem apenas uma licença para circular livremente. Eles possuem, além da licença, a autorização para exigir a livre locomoção mesmo em situações excepcionais. Todos nós possuímos o direito-licença para ir e vir e circular livremente pelo território. No entanto, existem condições excepcionais que autorizam o bloqueio desse direito-permissão a todos os cidadãos. É aí que, no caso da diplomacia, entram as imunidades diplomáticas, pois não se espera apenas que o diplomata exerça o seu direito de ir e vir, tendo em vista que cabe também ao destinatário a realização do direito.

A imunidade é uma exceção que recai sobre o titular, visto que, enquanto todos os outros indivíduos estão submetidos a obrigações e encargos oriundos da lei, o detentor do direito, por seu turno, está imune e dispensado, não precisando acatar tais obrigações do mesmo modo que os outros. Enquanto o poder e a permissão se constituem como direitos que dependem da ação positiva do seu detentor e, por consequência, da omissão do destinatário, a "imunidade" é independente do titular e deve ser assegurada pelo destinatário, como uma espécie de proteção ao exercício de outros direitos por parte do seu titular. No caso da diplomacia, podemos identificar a permissão que o diplomata possui para transitar livremente pelo território em batalha. Mas, mais do que isso, os exércitos dos países em guerra se constituem como os destinatários do direito-imunidade, de modo que devem assegurar a livre circulação dos diplomatas pelo território.

${ }^{37}$ Artigo 53, § 3º Constituição da República Federativa do Brasil de 1988. 


\section{UMA ESTRUTURA MOLECULAR}

Esse jogo de relações envolvendo os vários usos da palavra "direitos" mostra que o termo é entendido a partir de alguns significados distintos que moldam e constituem a complexidade dos direitos. Tratam-se de relações desenhadas a partir de elementos básicos, em especial por exigências e liberdades; elementos que servem como os ingredientes primários para a construção dos direitos, que se apresentam como a matéria-prima a partir da qual os direitos ganharão corpo no ordenamento jurídico e serão sobrepostos uns aos outros para construir uma grande composição a qual também nos referimos com o termo "direitos".

Muitos direitos fundamentais e direitos humanos são direitos subjetivos complexos, isto é, são direitos constituídos por diversos direitos subjetivos, de modo que é possível desmembrar esses vários direitos para, inclusive, analisá-los separadamente. Se observarmos o fenômeno jurídico, veremos que o direito à propriedade reside na possibilidade de o proprietário usar e dispor da sua propriedade. Há, por certo, uma escolha no exercício desse direito. No entanto, outras modalidades de escolhas também se apresentam ao proprietário, de modo que ele pode alienar o bem e criar novas relações obrigações e, portanto, novos direitos.

Nesse sentido, a análise filosófica da expressão linguística "direitos" nasce de uma liberdade básica e vai se complexificando na medida em que permissões, poderes e imunidades vão moldando aquela liberdade básica. Permissões, poderes e imunidades se unem em torno de um mesmo objeto ao qual nos referimos com o termo "direito", quando, por exemplo, falamos em liberdade de expressão e em direito à propriedade privada. Acerca dessa temática, Mackie aborda que: "Uma liberdade e uma exigênciadireito vinculada podem andar juntas (...). São, em geral, aglomerados de direitos (...).” (MACKIE, 1990, p. 173-174, tradução nossa) ${ }^{38}$. Do mesmo modo pensa Thomson, para quem as liberdades constituem um conjunto de direitos:

Pessoas têm exigências, e exigências são direitos. Pessoas também têm privilégios, e seus privilégios são direitos também. Pessoas têm liberdades, e liberdades não são elas mesmas privilégios: a liberdade de fazer isto ou aquilo inclui privilégios de fazê-lo e exige a não-interferência com o fazê-lo. Liberdades são aglomerados de direitos, e são eles próprios direitos. Muitos outros direitos familiares que levam-nos a ter também de aglomerados de direitos (THOMSON, 1990, p. 56, grifo do autor, tradução nossa). ${ }^{39}$

\footnotetext{
${ }^{38} \mathrm{~A}$ liberty and a related claim-right may go together (...). There often are clusters of rights (...) (MACKIE, 1990, p. 173-174).

${ }^{39}$ People have claims, and claims are rights. People also have privileges, and their privileges are rights too. People have liberties, and liberties are not themselves privileges: the liberty to do this or that includes privileges of doing it and claims to noninterference with doing it. Liberties are clusters of rights, and are themselves rights. Many other familiar rights that we take ourselves to have are also cluster-rights (THOMSON, 1990, p. 56, grifo do autor).
} 
Os direitos - principalmente, em questões polêmicas envolvendo direitos fundamentais e direitos humanos - constituem-se como conglomerados de direitos elementares costurados entre si; clusters of rights; são direitos basilares que, ao se costurarem, formam direitos cada vez mais complexos; direitos compostos, assim, por direitos atômicos, conforme afirma Wenar ao fazer uma analogia com os elementos químicos da tabela periódica: esses direitos constituem "(...) a unidade de moléculas compostas por átomos da tabela periódica." (WENAR, 2005, p. 237, tradução nossa) ${ }^{40}$. Com isso, Wenar propõe uma perspectiva pluralista ao definir a natureza dos direitos a partir da definição de diversos elementos atômicos que se unem para formar aquilo que designamos com expressões, como "direitos humanos" e "direitos fundamentais". Sumner também defende uma postura semelhante à de Wenar para a análise dos direitos, que a classifica como "uma visão que é complexa e pluralista" (SUMNER, 1987, p. 33, tradução nossa) ${ }^{41}$. Nesse sentido, prossegue Sumner: “(...) os direitos são complexos, assim como todo o direito consiste em um pacote de posições diferentes. (...) uma versão pluralista permitiria diferentes direitos para consistirem em diferentes posições (embora apenas uma em cada caso).” (SUMNER, 1987, p. 32-33, tradução nossa $)^{42}$.

Portanto, pode-se dizer que, em geral, quando estamos diante dos casos concretos mais complexos de um sistema jurídica - que, em geral, envolvem questões de direitos fundamentais e de direitos humanos -, é possível distinguir os direitos em suas partículas mínimas, como o são as permissões, os poderes e as imunidades, para, no movimento que vai das partes para o todo, mostrar como se dá a formação de novos direitos e, mais do que isso, como o ordenamento jurídico adquire dinamicidade ao se constituir como um todo unitário e coerente. A palavra "direitos" é, então, concebida dentro de um sistema normativo de regras jurídicas, de modo que as liberdades e as exigências constituem os pilares que darão sustentação às combinações entre os direitos (permissões, poderes e imunidades), dando origem a todos aqueles direitos que classificamos como legais, institucionais, convencionais, positivados e, até mesmo, aos direitos fundamentais e aos direitos humanos.

Nesse ponto, temos que retomar aquele esclarecimento proposto no início do presente artigo, a saber, a distinção entre direitos de primeira ordem e direitos de segunda ordem, conforme aponta Benn: "Uma distinção de alguma importância pode ser feita entre as relações de primeira ordem (isto é, exigências-deveres e privilégios-não direitos) e relações de segunda ordem (isto é, poderes-sujeições e imunidades-

\footnotetext{
${ }^{40}$ (...) it is the unity of molecules composed of the atoms of the periodic table (WENAR, 2005, p. 237).

${ }^{41}$ (...) a view which is both complex and pluralistic (SUMNER, 1987, p. 33).

42 (...) rights are complex, thus that every right consists of some bundle of different positions. (...) a pluralistic version would allow different rights to consist of different positions (though only one in each case) (SUMNER, 1987, p. 32-33).
} 
incapacidades)" (BENN, 1972, p. 196) ${ }^{43}$. A distinção entre dois níveis normativos para a linguagem dos direitos é uma das principais propostas do positivismo moderado de Herbert Hart, que define o Direito como a união entre regras primárias e regras secundárias. As primárias referem-se à conduta dos seres humanos, enquanto as secundárias são parasitárias às primárias. As regras secundárias se grudam às regras primárias para estabelecer regras que regulam a formação de novas regras e, por consequência, a formação de novos direitos. Diz Hart:

As normas de um tipo, que pode ser considerado o tipo básico ou primário, exigem que os seres humanos pratiquem ou se abstenham de praticar certos atos, quer queiram, quer não. As normas do outro tipo são, num certo sentido, parasitárias ou secundárias em relação às primeiras, pois estipulam que os seres humanos podem, ao fazer ou dizer certas coisas, introduzir novas normas do tipo principal, extinguir ou modificar normas antigas ou determinar de várias formas sua incidência, ou ainda controlar sua aplicação. As normas do primeiro tipo impõem deveres; as do segundo tipo outorgam poderes, sejam públicos ou privados (HART, 2009, p. 105). ${ }^{44}$

A partir dessa distinção entre primeira e segunda ordens, podemos compreender a dinâmica do ordenamento jurídico. Observa-se que as permissões constituem direitos de "primeira ordem", pois recaem diretamente sobre um determinado objeto e se dirigem à conduta e ao comportamento dos seres humanos. Se a linguagem dos direitos permanecesse inerte na alçada da "permissão", o sistema jurídico seria um sistema fechado e estático. Nenhuma mudança seria incorporada nesse sistema jurídico.

Para trazer dinâmica ao sistema jurídico, faz-se necessário inserir outros sentidos à palavra "direitos" e, como vimos ao longo do texto, considerá-los como "poder" e "imunidade". Estes últimos, por sua vez, se constituem a partir de "permissões" e "exigências" previamente constituídas e, por isso, são denominados direitos de "segunda ordem". Nesse sentido, Sumner destaca o papel dinamizador que poderes e imunidades desempenham na formação e na alteração dos direitos: "Com a noção de um poder e uma imunidade na mão, podemos mapear as conexões lógicas entre as várias relações hohfeldianas de segunda ordem." (SUMNER, 1987, p. 30, tradução nossa) ${ }^{45}$. Sobre os direitos de segunda ordem, prossegue Sumner:

\footnotetext{
${ }^{43} \mathrm{~A}$ distinction of some importance might be made between first-order relations (that is, claims-duties and privileges-no-rights) and second-order relations (that is, powers - liabilities and immunities - disabilities) (BENN, 1972, p. 196).

${ }^{44}$ Under rules of the one type, which may well be considered the basic or primary type, human beings are required to do or abstain from certain actions, whether they wish to or not. Rules of the other type are in a sense parasitic upon or secondary to the first; for they provide that human beings may by doing or saying certain things introduce new rules of the primary type, extinguish or modify old ones, or in various ways determine their incidence or control their operations. (HART, 1994, p. 81).

${ }^{45}$ With the notion of a power and an immunity in hand, we can map the logical connections among the various second-order Hohfeldian relations (SUMNER, 1987, p. 30).
}

52 - R. Opin. Jur., Fortaleza, ano 20, n. 33, p.31-59, jan./abr. 2022 
Nosso próximo conjunto de concepções será composto por operações de segunda ordem sobre essas relações. As regras que definem essas operações têm a função não de regular ou dirigir a conduta, mas de permitir ou facilitála. Elas, portanto, determinam não o que poderíamos fazer, mas o que podemos fazer, não o que é permitido, mas que é possível. Assim como as modalidades deônticas (obrigatório/proibido/permitido) fornecem os materiais para a construção de nossas relações de primeira ordem, as modalidades aléticas (necessário/impossível/possivel) irá fornecer os materiais para a construção de nossas relações de segunda ordem (SUMNER, 1987, p. 27-28, tradução nossa). ${ }^{46}$

Com isso, podemos perceber a dinâmica que os direitos adquirem com a distinção entre níveis de primeira e segunda ordem, de modo que esses direitos vão sendo construídos justamente a partir dessa dinâmica, conforme afirmou Sumner:

Diferentes permutações sobre liberdades, exigências, poderes e imunidades produzirão, sem dúvida, diferentes variedades de direitos. Além disso, os níveis de posições hohfeldianas envolvidas em um direito pode ser repetido indefinidamente, posições de primeira ordem que implicam posições de segunda ordem que fornecem, por sua vez, o conteúdo sobre posições de terceira ordem, e assim por diante. Nesta concepção, portanto, um direito não pode consistir em nada além de uma posição de primeira ordem hohfeldiana (SUMNER, 1987, p. 46, tradução nossa) ${ }^{47}$.

Os direitos de segunda ordem são direitos que se estruturam e se organizam a partir de (ou sobre os) direitos de "primeira ordem" e visam alterar não propriamente um comportamento, mas um direito já constituído. Esses direitos trazem dinamismo e movimento a um sistema de regras que, se fosse constituído apenas por direitos de primeira ordem, não passaria de um sistema estático e petrificado ao longo do tempo. Sem os direitos de segunda ordem, os direitos que constituem o sistema jurídico permaneceriam sempre os mesmos e nunca mudariam - o que é, justamente, o contrário do que realmente ocorre com os sistemas jurídicos.

\subsection{UM EXEMPLO DE ESTRUTURA MOLECULAR E COMPLEXA: O CASO DO DIREITO À PROPRIEDADE PRIVADA}

\footnotetext{
${ }^{46}$ Our next set of conceptions will consist of second-order operations on those relations. The rules which define these operations have the function not of regulating or directing conduct but of enabling or facilitating it. They therefore determine not what we may do but what we can do, not what is permissible but what is possible. Just as the deontic modalities (required/forbidden/permitted) provided the materials for constructing our first-order relations, the alethic modalities (necessary/impossible/possible) will provide the materials for constructing our second-order relations (SUMNER, 1987, p. 27-28).

${ }^{47}$ Different permutations of liberties, claims, powers, and immunities will doubtless yield different varieties of rights. Furthermore, the levels of Hohfeldian positions involved in a right may be iterated indefinitely, first-order positions entailing second-order positions which in turn furnish the contents of third-order positions, and so on. On this conception, therefore, a right cannot consist of nothing but a first-order Hohfeldian position (SUMNER, 1987, p. 46).
} 
Vejamos o caso do direito à propriedade ${ }^{48}$, que é um direito humano fundamental. Se pegarmos, aliás, todos direitos herdados pela tradição liberal-burguesa, veremos que a propriedade ocupa um lugar de destaque na hierarquia e na organização dos direitos, tendo, muitas vezes, prioridade, até mesmo, sobre a vida das outras pessoas. Isso não significa que a propriedade valha mais do que a vida, mas, ao contrário, a vida é, conforme diria Locke, um desdobramento da propriedade dos indivíduos, conforme explica Locke ao afirmar que o homem é proprietário de si mesmo: “(...) cada homem tem uma propriedade em sua própria pessoa; a essa ninguém tem qualquer direito senão ele mesmo. O trabalho do seu corpo e a obra de suas mãos, pode dizer-se, são propriamente dele." (LOCKE, 1978, p. 45) ${ }^{49}$. Locke tomava a propriedade privada como uma consequência da self-ownership (propriedade de si), e, nesse sentido, se apontarmos para o exemplo da propriedade e o analisarmos a partir da correlação entre direitos e deveres, poderemos observar que, se "X" possui o direito à propriedade $\mathrm{R}$ (levando-se em conta que $\mathrm{R}$ diz respeito à vida), é porque "Y", o destinatário do direito, não está autorizado a possuir esse direito. Y possui o dever de não interferir no direito de $\mathrm{X}$.

A partir de um primeiro direito, outros direitos vão sendo estruturados em um andaime complexo no qual direitos são agrupados entre si em razão de suas características básicas. Nesse sentido, o quadro abaixo, proposto por Wenar (2015), mostra a estrutura molecular dos direitos quando se diz que se possui uma determinada coisa, como um computador que pode ser usado por seu próprio dono de múltiplas maneiras. O proprietário está autorizado a usar a sua própria coisa. Por isso, diz-se que o detentor do direito à propriedade possui uma "autorização" ou uma "permissão" para usar o bem. Podemos ir além e analisar os direitos de segunda ordem.

Se pegarmos o direito-liberdade classificado como "poder", veremos que o proprietário pode não só usar a sua coisa, como pode também criar novas relações jurídicas a partir dela. $\mathrm{O}$ proprietário pode transferir o seu direito ao uso para outras pessoas: ele pode, por exemplo, emprestar o computador, vendê-lo ou doá-lo à outra pessoa. Além de possuir poder, o proprietário pode, ainda, possuir uma imunidade. Nesse caso, temos que supor a possibilidade de outra pessoa estar autorizada (e, por isso, sob sua perspectiva, também possuir um direito-permissão) a alterar o direito de propriedade dos donos de computador. Vamos supor que o Estado, por meio de seus agentes de fiscalização, possa cobrar determinado tributo de todos os donos de computadores, como o faz no caso dos automóveis, com o Imposto sobre a Propriedade

\footnotetext{
${ }^{48}$ No presente artigo, não estamos interessados em analisar, estritamente, o conceito de propriedade privada. Nosso foco é com a linguagem dos direitos e, no caso do direito à propriedade privada, interessa-nos mais a noção de direito ali contida do que propriamente a noção de propriedade privada. Feita essa ressalva, sugere-se a seguinte leitura: WALDRON, 2012.

${ }^{49}$ (...) every man has a property in his own person: this no body has any right to but himself. The labour of his body, and the work of his hands, we may say, are properly his. (LOCKE, 1980, Ch. V § 27, p. 19, grifos do autor).
} 
de Veículos Automotores (IPVA), e, no caso dos bens imóveis urbanos, como o Imposto Predial Territorial Urbano (IPTU). Todos os titulares do direito a essas propriedades devem pagar os referidos impostos. No entanto, verificam-se casos nos quais os proprietários, por alguma razão justificada pela norma jurídica, estão isentos ao pagamento dos respectivos impostos. É o caso, por exemplo, da imunidade tributária que recai para os proprietários de imóveis destinados a templos de qualquer culto, patrimônio de partidos políticos, jornais, dentre outras circunstâncias estabelecidas no art. 150, VI, da Constituição Federal de 1988. Dadas determinadas circunstâncias, o proprietário pode estar imune a algo que, para os terceiros, é sempre obrigatório.

Wenar se vale do exemplo dos direitos que possui o proprietário de um computador para mostrar, a partir de um quadro esquemático, como os direitos podem ser distinguíveis e como podem interagir entre si para construir direitos complexos. Segue o quadro esquemático de Wenar:

Figura 1 - A estrutura molecular dos direitos

\begin{tabular}{|l|l|l|}
\hline $\begin{array}{l}\text { POCÊ TEM } \\
\begin{array}{l}\text { Para renunciar, } \\
\text { anular } \\
\text { ou transferir seu }\end{array}\end{array}$ & $\begin{array}{l}\text { IMUNIDADE } \\
\text { Contra outros } \\
\text { alterarem o seu }\end{array}$ & $\begin{array}{l}\text { segunda-ordem: } \\
\text { Direitos } \\
\text { sobre os } \\
\text { direitos de } \\
\text { primeira ordem }\end{array}$ \\
\hline $\begin{array}{l}\text { PRIVILÉGIO } \\
\text { Oara usar }\end{array}$ & $\begin{array}{l}\text { EXIGÊNCIA } \\
\text { Contra outros } \\
\text { usarem o computador }\end{array}$ & $\begin{array}{l}\text { direitos } \\
\text { sobre o } \\
\text { computador }\end{array}$ \\
\hline
\end{tabular}

Fonte: (WENAR, 2015, online).

$\mathrm{Na}$ raiz do direito à vida, encontra-se uma exigência semelhante à do direito de propriedade, que é a exigência que todo o indivíduo enuncia com o objetivo de governar o seu próprio corpo, a sua vida e os seus pertences pessoais. A exigência básica que todo indivíduo faz para os demais com o objetivo de se autopreservar é a de que ninguém toque o seu próprio corpo. $\mathrm{O}$ direito ao corpo e à preservação de sua própria vida, ou mesmo o direito à propriedade são construções moleculares a partir de direitos atomizados.

Todo indivíduo exige naturalmente que os outros indivíduos dele se mantenham afastados e não toquem no seu próprio corpo ou nos seus pertences pessoais. A partir desse tipo de exigência, surge uma autorização ou permissão que lhe permite fazer ou deixar de fazer o que bem entender de sua propriedade ou do seu próprio corpo e, enfim, da sua própria vida, sem ser interrompido por ninguém. Essa autorização ou permissão é entendida como "liberdade" porque o seu titular possui, por exemplo, a 
liberdade de se locomover, de ir e vir, e, portanto, de entrar e sair (isto é, usar, usufruir e gozar) da sua propriedade no momento e do modo como determinar o seu próprio querer. Além disso, o proprietário não apenas possui uma autorização e encontra-se na posição de exigir direitos em relação a terceiros, como também pode repassar essa permissão e essa posição de exigência à outra pessoa, que, por sua vez, poderá exercer o mesmo direito que seu proprietário de origem. O proprietário, por exemplo, não só possui a permissão de entrar e sair da propriedade, como tem também o "poder" de incumbir seus familiares, amigos e empregados a gozarem do mesmo direito que possui, permitindo-lhes entrar e sair da propriedade como se fossem os efetivos detentores do direito. No caso da imunidade, o titular do direito está protegido em relação a terceiros, no sentido de que esses não podem renunciar ou extinguir o seu direito básico de manipular o próprio corpo e usufruir da sua propriedade da forma que mais the convir.

\section{CONSIDERAÇÕES FINAIS}

A linguagem dos direitos subjetivos pode ser compreendida a partir de uma descrição dos modos com os quais usamos as liberdades individuais, em especial as permissões, os poderes e as imunidades. Os direitos-liberdades podem ser distinguidos em suas partículas mínimas para, a partir de um jogo de relações que se desenha entre o portador de um direito e o seu destinatário, mostrar que aquilo que nos referimos com a palavra "direito" é, no fundo, uma composição de diversos tipos de direitos que, quando reunidos em um só elemento, vão dando sentido e significado para aquilo que juristas e legisladores entendem como o mais adequado para se referir às múltiplas definições dos direitos.

A observação da linguagem jurídica, mais precisamente a partir da observação empírica do emprego da palavra "direitos" nos seus mais variados usos e contextos, mostra que essas palavras são usadas para se referir a algum tipo de liberdade, como a permissão, o poder e/ou a imunidade. O uso dessa linguagem é corrente não apenas no meio de juristas e legisladores, mas também no senso comum quando os cidadãos estão diante de contratos particulares. $\mathrm{O}$ uso dessa linguagem também está presente no discurso dos direitos humanos e dos direitos fundamentais. A definição dos "direitos" depende da verificação da estrutura molecular segundo a qual esses direitos se entrelaçam em conglomerados de direitos elementares costurados entre si - cluster of rights. São direitos basilares que, ao se costurarem, formam direitos cada vez mais complexos; direitos que dão dinâmica ao sistema jurídico, ao desempenharem funções distintas entre os pares de uma relação jurídica, dependendo da função que atribuem ao detentor e ao destinatário. 


\section{REFERÊNCIAS}

AUSTIN, John. 1885. Lectures on jurisprudence, or the philosophy of positive law. London: The Lawbook Exchange, Ltd., 2005.

AUSTIN, John Langshaw. 1962. How to do things with words. Oxford: Oxford University Press, 1975.

BENN, Stanley I. RIGHTS. In: EDWARDS, Paul (ed.). Encyclopedia of Philosophy. New York: Macmillan, 1972. v. 7. p. 195-199.

BENTHAM, Jeremy. 1789. An introduction to the principles of morals and legislation. Oxford: Claredon Press, 2012.

BENTHAM, Jeremy. 1789. Uma introdução aos princípios da moral e da legislação. Tradução de Luiz João Baraúna. São Paulo: Abril Cultural, 1974. p. 7-74. (Os Pensadores).

BLACK, Henry Campbell. Black`s law dictionary: definitions of the terms and phrases of American and English jurisprudence, ancient and modern. 6th ed. St. Paul: West Publishing, 1990. p. 1323-1324.

BRASIL. [Constituição (1988)]. Constituição da República Federativa do Brasil de 1988. Brasília, DF: Presidência da República, 1988. Disponível em: http://www.planalto.gov.br/ccivil_03/constituicao/constituicao.htm. Acesso em: 17 dez. 2019.

CLAYTON, Richard; TOMLINSON, Hugh (ed.). The law of human rights. 2th ed. New York/Oxford: Oxford University Press, 2009. v. 1. 2193p.

EDMUNDSON, William A. 2004. An Introduction to Rights. Cambridge: Cambridge University Press, 2004. 223p.

FEINBERG, Joel. Social Philosophy. New Jersey: Englewood Cliffs, N.J, Prentice-Hal, 1973. 126p.

FEINBERG, Joel. 1973. Filosofia social. Tradução de Alzira Soares da Rocha e Helena Maria Camacho. Rio de Janeiro: Zahar, 1974. 178p.

FEINBERG, Joel. The nature and value of rights. Journal of Value Inquiry, v. 4, p. $243-$ 257, winter $1970 . \quad$ Disponível em: http://www.law.georgetown.edu/faculty/lpw/documents/FeinbergNatureandValueofRi ghtsexcerpt.pdf. Acesso em: 13 mar. 2018.

HART, Herbert Lionel Alphonsus. 1961. O conceito de direito. São Paulo: Martins Fontes, 2009. 399p.

HART, Herbert Lionel Alphonsus. 1961. The concept of law. 2. ed. Oxford: Oxford University Press, 1994. 315p.

HART, Herbert Lionel Alphonsus. Ensaios sobre teoria do direito e filosofia. Tradução de José Garcez Ghirardi e Lenita Maria Rimoli Esteves. Rio de Janeiro: Elsevier, 2010. Coleção Teoria e Filosofia do Direito. p. 23-52. 
HART, Herbert Lionel Alphonsus. 1983. Definition and theory in jurisprudence. Essays in Jurisprudence and Philosophy. Oxford, Clarendon Press, 1983. p. 21-48.

HOHFELD, Wesley Newcomb. Fundamental legal conceptions as applied in judicial reasoning. Edited by David Campbell and Philip A. Thomas; with an introduction by Nigel E. Simmonds. Ashgate: Aldershot, 2001. 112p. (Classical jurisprudence series).

JONES, Peter. Rights: issues in political theory. Hampshire: Palgrave/Macmillan Press, 1994. 258p.

LOCKE, John. 1689. Second treatise of government. Edited by C. B. Macpherson. Inidianapolis. Cambridge: Hackett Publishing Company, 1980. 125p.

LOCKE, John. 1689. Segundo tratado sobre o governo. Tradução de E. Jacy Monteiro. São Paulo: Abril Cultural, 1978. p. 31-131. (Os Pensadores).

MACKIE, John Leslie. 1977. Ethics: inventing right and wrong. Harmondsworth: Penguin, 1990. 249p.

MCCLOSKEY, H. J. Rights. The Philosophical Quarterly, v. 15, n. 59, p. 115-127, 1965. Disponível em: http://www.jstor.org/stable/2218211. Acesso em: 9 jun. 2019.

MCCLOSKEY, H. J. Rights: some conceptual issues. Australasian Journal of Philosophy, v. 54, n. 2, p. 99-115, 1976. Disponível em: http://www.tandfonline.com/doi/abs/10.1080/00048407612341101. Acesso em: 9 jun. 2019.

OLIVIER, André. Os direitos humanos enquanto exigências e reivindicações mútuas. Novos Estudos Jurídicos, v. 19, n. 3, p. 1101-1123, 2014. Disponível em: https://siaiap32.univali.br/seer/index.php/nej/article/view/6680. Acesso em: 19 nov. 2019.

PENNER, J. E. The analysis of rights. Ratio Juris, v. 10, n. 3, p. 300-315, set. 1997. Disponível em: http://web.ebscohost.com/ehost/pdfviewer/pdfviewer?vid=3\&hid=126\& sid=65b09c6eaced-4884-86b7-d1d943dda472\%40sessionmgr115. Acesso em: 4 jun. 2019.

PLATTS, Mark. The languages of rights and of human rights. Philosophy, v. 85, n. 3, p. 319-340, jul. 2010. Disponível em: http://journals.cambridge.org/action/displayFulltext?type $=1 \&$ fid $=7808001 \&$ jid=PHI\& volumeId=85\& issueId=03\& aid $=7807999 \&$ bodyld $=\&$ membershipNumber $=\&$ societyET OCSession=. Acesso em: 20 maio 2019.

RAINBOLT, George W. Rights as Normative Constraints on Others. Philosophy and Phenomenological Research, v. 53, n. 1, p. 93-111, mar. 1993. Disponível em: http://www.jstor.org/stable/2108055. Acesso em: 4 jun. 2019.

RAZ, Joseph. Authority and justification. Philosophy \& Public Affairs, v. 14, n. 1, p. 3 29, winter 1985. Disponível em: http://www.jstor.org/stable/2265235. Acesso em: 6 jun. 2019. 
SUMNER, Leonard Wayne. The moral foundation of rights. New York: Oxford University Press, 1987. 224p.

THOMSON, Judith Jarvis. The realm of rights. Harvard University Press, 1990.

WALDRON, Jeremy. The right to private property. Oxford: Clarendon Press, 2012.

WENAR, Leif. RIGHTS. In: ZALTA, Edward N. (ed.). The Stanford Encyclopedia of Philosophy. 2015 Edition. Disponível em: https://plato.stanford.edu/entries/rights/. Acesso em: 12 mar. 2019.

WENAR, Leif. The analysis of rights. In: KRAMER, Matthew H.; GRANT, Claire; COLBURN, Ben; HATZISTAVROU, Antony. The Legacy of H.L.A. Hart. Oxford/New York: Oxford University Press, 2008. cap. 14, p. 251-274.

WENAR, Leif. The nature of rights. Philosophy \& Public Affairs, v. 33, n. 3, p. 223 253, summer 2005. Disponível em: http://www.jstor.org/stable/3557929. Acesso em: 16 dez. 2019.

WHITE, Alan R. Rights. Oxford: Clarendon Press, 1984.

Como citar este documento:

OLIVIER, André. A linguagem dos direitos subjetivos e as liberdades individuais: entre permissões, poderes e imunidades. Revista Opinião Jurídica, Fortaleza, v. 20, n. 33, p. 31-59, jan./abr. 2022 